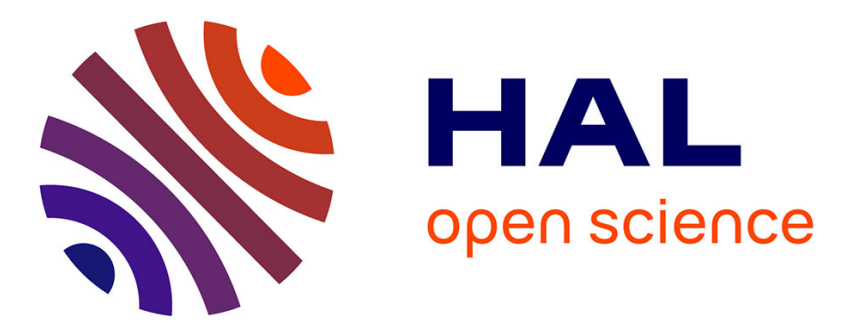

\title{
Late Roman and Byzantine mosaic opaque "glass-ceramics" tesserae (5th-9th century)
}

Elisabetta Neri, Cedric Morvan, Philippe Colomban, Maria Filomena Guerra, Vivien Prigent

\section{To cite this version:}

Elisabetta Neri, Cedric Morvan, Philippe Colomban, Maria Filomena Guerra, Vivien Prigent. Late Roman and Byzantine mosaic opaque "glass-ceramics" tesserae (5th-9th century). Ceramics International, 2016, 42, 10.1016/j.ceramint.2016.09.033 . hal-01375484

\section{HAL Id: hal-01375484 https://hal.sorbonne-universite.fr/hal-01375484}

Submitted on 3 Oct 2016

HAL is a multi-disciplinary open access archive for the deposit and dissemination of scientific research documents, whether they are published or not. The documents may come from teaching and research institutions in France or abroad, or from public or private research centers.
L'archive ouverte pluridisciplinaire HAL, est destinée au dépôt et à la diffusion de documents scientifiques de niveau recherche, publiés ou non, émanant des établissements d'enseignement et de recherche français ou étrangers, des laboratoires publics ou privés. 


\title{
Late Roman and Byzantine Mosaic opaque “Glass-ceramics" Tesserae $\left(5^{\text {th }}-9^{\text {th }}\right.$ century)
}

\author{
Elisabetta Neri ${ }^{1,2,4,5}$, Cedric Morvan ${ }^{1}$, Philippe Colomban ${ }^{1,2^{*}}$, Maria Filomena Guerra ${ }^{3}$, \\ Vivien Prigent ${ }^{4,5}$ \\ ${ }^{1}$ Sorbonne Universités, UPMC Université Paris 06, UMR 8233, MONARIS, 4 Place Jussieu, 75005 \\ Paris, France \\ ${ }^{2}$ CNRS, IP2CT, UMR 8233, MONARIS, 4 Place Jussieu, 75005 Paris, France \\ ${ }^{3}$ CNRS, UMR 8096, ArchAm, MAE, 21 Allée de l'Université, 92023 Nanterre, France. \\ ${ }^{4}$ Sorbonne Universités, Université Paris 04, 1, rue Victor Cousin, 75005, Paris, France \\ ${ }^{5}$ CNRS, UMR 8167, Orient \& Méditerranée, Centre Byzantin, rue du Cardinal Lemoine, 75005, Paris, \\ France
}

* Corresponding author at: Sorbonne Universités, UPMC Université Paris 06, UMR 8233, MONARIS, 4 Place Jussieu, 75005 Paris, France. E-mail address: philippe.colomban@upmc.fr

\begin{abstract}
Forty-two mosaic coloured/opaque "glass" tesserae from three sites (Milan, Italy; Durrës, Albania; Hierapolis, Turkey) situated in the Western and Eastern parts of the Roman/Byzantine Empire, dated between the $5^{\text {th }}$ and the $9^{\text {th }}$ centuries, were studied by optical microscopy, SEM-EDX and Raman microspectroscopy in order to investigate the nature of their pigments and opacifiers as well as the microstructure of glass ceramic materials. The Raman signatures of glass matrix and phases dispersed in the soda-lime glassy matrix showed the presence of six opacifiers/pigments. The use of soda ash glass in the tesserae from Durrës (post $8^{\text {th }} \mathrm{c}$.) allows refining the mosaic debated chronology. The use of soda ash matrix glass together with the presence of calcium antimonates $\left(\mathrm{Ca}_{2} \mathrm{Sb}_{2} \mathrm{O}_{7}\right.$ and $\left.\mathrm{CaSb}_{2} \mathrm{O}_{6}\right)$, pyrochlore solid solution/Naples' yellow $\left(\mathrm{PbSb}_{2-\mathrm{x}-\mathrm{y}} \mathrm{Sn}_{\mathrm{x}} \mathrm{M}_{\mathrm{y}} \mathrm{O}_{7-\delta}\right)$ and cuprite $\left(\mathrm{Cu}_{2} \mathrm{O}\right)$ or metallic copper $\left(\mathrm{Cu}^{\circ}\right)$ in many samples show the technological continuity in a Roman tradition. However, the presence of cassiterite $\left(\mathrm{SnO}_{2}\right)$ and quartz $\left(\mathrm{SiO}_{2}\right)$ in one sample from the beginning of the $5^{\text {th }}$ century, diverging from Roman technology, offers a chronological marker to identify newly (not re-used) produced tesserae.
\end{abstract}

\section{Graphical abstract}

Keywords: Microstructure-final; Spectroscopy; Glass ceramics; Colour; Byzantine/Roman Empire

\section{Highlights}

Opaque/coloured glass mosaic tesserae exhibit a glass ceramics microstructure.

The innovative use of cassiterite $\left(\mathrm{SnO}_{2}\right)$ and quartz $\left(\mathrm{SiO}_{2}\right)$ in $5^{\text {th }}$ century tesserae is evidenced.

The technological innovations went alongside the continual use of Roman recipes (calcium antimonate and yellow pigments).

\section{Novelty}

The first use of cassiterite and quartz in the beginning of the $5^{\text {th }} \mathrm{c}$. as well as the use of calcium antimonates after Roman times in the tesserae produced ex novo with mixed glasses were demonstrated. 


\section{Introduction}

Glass mosaics are considered among the most outstanding and elaborate forms of mural and floor decoration in Antiquity. From the Late Antique and Byzantine periods onwards, coloured glass and gold leaf tesserae covered large surfaces and were the prevalent material of wall mosaics [1]. Despite important interest for mosaic tesserae [2-7], the workshops where glass tesserae were made are still unknown. Moreover, analytical data available for Late Roman and Early Byzantine $\left(4^{\text {th }}-8^{\text {th }} \mathrm{c}\right.$.) tesserae, especially opaque tesserae, have not allowed accurate dating.

The large number of studies and chemical analyses performed on ancient (transparent) glass pieces over the last decades suggests that glass manufacturing was a two-stage process: first the production of glass ingots and then the manufacture of glass objects [8]. Abundant literature is also available on raw materials and their provenance, on the compositional classification of raw glass, and on the chronology of the glass objects (e.g. [9-11]). In these studies, a glass is considered as a homogeneous material and no attention was paid to the glass ceramic character of coloured/opacified samples. Glass tesserae from the $1^{\text {st }}$ to the $8^{\text {th }} \mathrm{c}$. were made from soda-lime glass characterized by low potassium, magnesium and phosphorus contents (so-called natron-type glass) [6, 12]. After the $8^{\text {th }} \mathrm{c}$. a new type of soda-lime-silica glass containing higher potassium, magnesium and phosphorus contents, produced with plant ashes rich in soda and lime, serving as flux, was introduced. However, both natron and ash glass continued to to be used side-by-side until the $12^{\text {th }}$ c., Note, some mixed-types, i.e.natron glass mixed with ash glass or ash, due to glass recycling have been also identified [4].

Some scholars suggested that mosaic tesserae produced from the $4^{\text {th }}-5^{\text {th }} \mathrm{c}$. onwards could originate either from the dismantling of older mosaics or the melting of cullet [13-19]. Surely, tesserae re-using was a widespread practice, attested by many sources from the $1^{\text {st }}$ to the $12^{\text {th }}$ c. $[2,8,20]$, but it is nowadays impossible to define the ratio between re-use and new production.

The split of production between primary workshops, which melt glass ingots, and secondary workshops, which fabricated artefacts, has important impact on the interpretation of the analytical data. Consequently, the chemical composition of the tesserae based glass is not specific to the workshop producing the artefact, but rather to the primary infrastructure producing the raw material. Since the addition of colouring and opacifying agents to prepare a glass mosaic cake is a complex process (first a glass cake is made, and then the mosaic master cuts it in tesserae pieces), their identification make difficult the location of the secondary workshop where the glassy cakes were made.

It was reported that the glass coloration technology did not evolve significantly between the $1^{\text {st }}$ and the $9^{\text {th }}$ c. [21]. Actually, optically clear glass colour was mainly due to transition metal ions dissolved in the glass network, usually iron $\left(\mathrm{Fe}^{2+} / \mathrm{Fe}^{3+}\right)$, cobalt $\left(\mathrm{Co}^{2+}\right)$, copper $\left(\mathrm{Cu}^{2+}\right)$ and manganese $\left(\mathrm{Mn}^{2+}, \mathrm{Mn}^{3+}\right)$. Other colouring effects were produced by forming a glass-metal composite by the dispersion of metal nanoparticles, namely copper [22-24], silver [22,25] and gold [22,26]. The high absorption of the metal particle plasmon requires however special manufacturing techniques in order to keep a low concentration of metal particles (limited diffusion from the surface, alternation of colourless and coloured thin layers, atmosphere control, etc. [22]). Lastly, colour can be obtained by forming a glass ceramic: a pigment is dispersed in a glass or precipitation on cooling is favoured through the saturation of molten glass.

Opacification arises from the difference in optical index between the glass matrix and second phase(s). Opacity is obtained by the incorporating a phase with a higher 
optical index than the matrix one into the transparent matrix, generally a crystalline phase. Alternatively, intentionally generating (sub)micron gas bubbles [27] cause light scattering. Antimony-based opacifiers, namely white calcium antimonate, were used from the beginning of glass production in the Near East and Egypt, around $1500 \mathrm{BC}$, until the Roman period [28-30], but were subsequently replaced by tin oxide [28, 3133]. These opacifiers remained in the use until the Renaissance and even modern times. Calcium phosphate was also used as opacifier from the $5^{\text {th }}$ c. onwards, especially in the Eastern Mediterranean [34-40]. From the $10^{\text {th }} \mathrm{c}$. onwards, Byzantine glassmakers produced mosaic tesserae employing quartz (ground silica sand), a less efficient but extremely cheap opacifier [41-43]. So the hue is a combination of the contribution of the transition element ions (colorants) and the quantity of the opacifiers.

The chronological evolution of the opacifiers can be used:

1. To distinguish new production from re-used one:

- re-use, if the techniques used in Roman times have been attested in later mosaics;

- new production, if technological discontinuities have been observed with respect to Roman technology;

2. to determine secondary glassmaking workshops and supply routes, if the different opacification techniques could be linked to the specific areas of production.

This study presents the identification of glass tesserae opacifier agents within forty-two tesserae, sampled from three sites situated in the Western and Eastern areas of the Roman/Byzantine Empire, and dated between the $5^{\text {th }}$ and the $9^{\text {th }}$ centuries, analysed by SEM-EDX and Raman spectroscopy. The earliest samples correspond chronologically to the first evidence of technological changes in opacification $\left(5^{\text {th }} \mathrm{c}\right.$.), which delimited the start of a period ending with the introduction of a new raw glass ceramic production technology during the $9^{\text {th }}$ century.

Each site has a disputed chronology as follows:

Italy, Milan: loose tesserae found during the excavations conducted in the church of St. Lawrence from 1913 to 1920 (Supporting information, Fig. S1a) document the vault decoration of this celebrated building, likely dated to the $5^{\text {th }}$ c. [44]. In particular loose tesserae from St. Aquilino, the octagonal chapel of St. Lawrence, have been sampled: the use of stylistic criteria provided us a wide chronological milestone (late $4^{\text {th }}$ or $5^{\text {th }}$ c.) and allowed to identify the work of craftsmen of different origins (local or Levantine).

Albania, Durrës: the in situ Byzantine mosaic in the Christian chapel inside the amphitheatre has been controversially dated between the $6^{\text {th }}$ and the $8^{\text {th }}$ c. $[45,46]$ (Supporting information, Fig. S1b).

Turkey, Hierapolis: loose tesserae were found during archaeological excavations inside the Theatre, in the demolition layers (before $9^{\text {th }}$ c.), and in the St. Philip church $\left(6^{\text {th }}-9^{\text {th }} \mathrm{c}\right)$. The Theatre tesserae were assigned to the $6^{\text {th }} \mathrm{c}$. wall decoration of an unknown church whereas the St. Philip one, to the demolition layers dated from the Seldjuk period (1037-1194). Then Tesserae and mosaic fragments were assigned to the $6^{\text {th }} \mathrm{c}$. wall decoration of the St. Philip church and its restoration performed in the $9^{\text {th }} \mathrm{c}$. [47] (Supporting information, Fig. S1c).

To identify the opacification techniques and to document the technological changes between Roman and Byzantine eras, tesserae were analysed not only by optical microscopy and SEM-EDX, but also by Raman spectroscopy. Note, this technique is a powerful tool for the non-invasive analysis of materials $[48,49]$ that characterizes both 
the silicate network (nanostructure and microstructure heterogeneity) [50-55] and the crystalline secondary phases $[2,3,7,50,56-58]$. Despite the interest for the identification of crystalline phases, very few Raman analyses of ancient mosaic tesserae have been published $[2,3,7,57,58]$.

\section{Materials and Experimental Methods}

Forty-two tesserae from three sites are selected (described in Fig. 1 and Supporting information, Fig. S1; several details are given in Table S1). Typical dimensions are comprised between $5 \times 5 \times 7$ and $9 \times 9 \times 12 \mathrm{~mm}^{3}$. The samples were carefully observed in order to define colours and optical characteristics of the glass. Because of the surface deterioration of most of the tesserae, appearing as a yellowish and whitish weathered surface layer, a soft mechanical abrasion was performed with ' 1200 ' grade $\mathrm{SiC}$ paper under the optical microscope to identify chromatic hues and to facilitate the microstructure examination. As far as possible, all the macro-coloured areas were analysed in all the different hues. Some tesserae were polished using SiC paper and diamond paste felts before the SEM-EDS analysis and by Raman spectroscopy (Fig. 1a). Ten representative tesserae were selected for EDS analysis.

Optical Microscopy: the polished sections were observed under a Wild-Heerberg stereomicroscope coupled to multiple magnifications (5x and 10x objectives) and a Olympus BX51 Olympus + Th4-200 microscope (100x objective) for finer observations (Fig. 2).

SEM-EDS: chemical analysis and images were obtained under a JEOL 5410LV SEM-EDX using an acceleration voltage of $20 \mathrm{kV}$. Quantitative elemental analysis was performed (oxide) with Iridium Ultra software based on the ZAF calculation method. The validity of the measurements was monitored by applying the same procedure to certified glass-reference samples "Corning Museum B, C and D" and American "National Bureau of Standard (NBS 620)", as usual [59-61]. The error is below 1\% for $\mathrm{SiO}_{2}, \mathrm{Na}_{2} \mathrm{O}$ and $\mathrm{CaO}$, and below $5 \%$ for the other oxides.

Raman microspectroscopy: the analysis was carried out by Raman spectroscopy using two different instruments excited with blue and green laser, respectively (blue excitation is well adapted to record the spectrum of poor coloured silicate glasses and the green excitation offers a good compromise whatever the colour of the analyzed material):

- a LabRam HR 800 spectrometer (HORIBA Scientific, Longjumeau, France) coupled to an Olympus BX microscope (10x, 50x, and 100x standard and long working distance objectives), equipped with a Coherent $\mathrm{Ar}^{+}$ion laser. Here the $458 \mathrm{~nm}$, blue line, is used. The scanned areas range between $\sim 10^{4}$ and $5 \mu \mathrm{m}^{2}$ as a function of the objective magnification.

- a LabRam Infinity spectrometer (Dilor, Lille, France) coupled to a BX microscope, equipped with a Nd:YAG green laser (532 nm).

In order to select the different spots to be analysed by Raman scattering, the crystalline phases and the glass matrix have been examined first under the optical microscope to. Spectra were processed by LabSpec software. A linear segment baseline was applied to remove the fluorescence background making the comparison of the spectra recorded with different instruments more reliable [62]: the spectral components/background including the Boson peak were removed to keep the bending and stretching components of $\mathrm{SiO}_{4}$ vibrational unit only.

\section{Results and discussion}


The tesserae have heterogeneous structure: crystalline phases are dispersed in the glass matrix (Fig. 2) leading to a glass ceramic material. In the most abundant yellow, green-yellow and green tesserae, yellow crystals are dispersed in colourless or green glass with bubbles, as a few tens of micrometres in size individuals or aggregates. In some points the individual and aggregates are arranged in layers (Fig. $\mathbf{2 b}$ and $\mathbf{2 d}$ ), which indicates that two mixtures were added to the molten matter and roughly mixed. In the case of blue and turquoise tesserae, white crystallised grains up to $150 \mu \mathrm{m}$ in size were observed, more abundant in the light blue tesserae, because they were used to whiten the colours and obtain many hues. Their large dimensions indicate that they were added to the glass precursor. The bubbles (Fig. S2a) and rare aggregates of white crystals give rise to the translucent to opaque aspect of many tesserae. The red and orange tesserae show 'dark' layers on optical micrographs (Fig. 2c). These layers are actually transparent green zones free of pigments, interspersed with coloured opaque red zones that are commonly observed in a glass coloured by metal copper nanoparticles [24].

The compositional data obtained for 10 tesserae glass are given in Table 1. Representative Raman signatures of the glass matrix are shown in Fig. 3, and crystalline phases in Fig. 5. Composition biplots are presented in Fig. 4.

\subsection{Glass matrix}

The different compositions of the glass matrix are identified in Table 1. These compositional groups were obtained by subtracting the contribution of the colorants, decolorants and opacifiers (Table 2) from the composition of the "coloured glass" matrix and then normalizing of the subtracted cr corrected data to $100 \mathrm{wt} \%$ In the case of tesserae DU_A_1, DU_A_3 their heterogeneous structure allows a specific analysis of glass matrix (without pigments). As shown in Table 1 and Fig. 4 a, the $\mathrm{MgO}$ and $\mathrm{K}_{2} \mathrm{O}$ contents are in agreement with the glass type prevailing in the Roman times until the $8^{\text {th }}-9^{\text {th }}$ c., a soda-lime-silica glass containing potassium and magnesium oxides below $1.5 \mathrm{wt} \%$ each and phosphorus oxide below $0.2 \mathrm{wt} \%$ [9]. Natron, a sodium carbonate mineral from Egypt associated with low amounts of chlorides and sulphates, was the flux used to produce this glass [11].

It is admitted that the natron was mixed and fused together with a silica-lime sand in which quartz and calcium carbonate were present in suitable ratios. The higher magnesium, potassium and phosphorus contents of two tesserae from Durrës (DU_A_2, DU_A 3) indicate a soda-lime-silica glass made from soda plant ashes [63]. This allowed dating the above-mentioned tesserae after the $8^{\text {th }} \mathrm{c}$. In the case of the two tesserae from Hierapolis, one exhibits a high magnesium content (HA_C_16) correlated to a high phosphorus content $\left(0.92 \mathrm{wt} \% \mathrm{P}_{2} \mathrm{O}_{5}\right.$, Table 1$)$, and the second ( $\mathrm{HA}$ _C_10) a higher potassium content $\left(1.95 \mathrm{wt} \% \mathrm{~K}_{2} \mathrm{O}\right.$, Table 1$)$. According to the published interpretations of the $6^{\text {th }}$ c. mosaics from Sagalassos [4], HA_C_10 glass could result from the contamination of soda ashes to natron-based glass, during the cooking in reducing atmosphere.

The $\mathrm{Al}_{2} \mathrm{O}_{3}$ and $\mathrm{CaO}$ contents (Table 1) depending on the sand employed in raw glass production, form three different groups. The first (N1 in Table 1) corresponds to the typical calcium/alumina content of Roman glass ( $\mathrm{CaO}$ between 4 to 7\%) [9] (samples HA_C_12, HA_C_13, SA_5_20, SA_6_18), the second (N2, in Table 1) corresponds to high calcium contents (sample $\bar{D} \bar{U}_{-} \mathrm{A}$ _2, ) ( $\mathrm{CaO}$ between $\left.9-11 \%\right)$ whereas the third (N3 in Table 1) can be assigned to high alumina and low calcium contents (samples HA_C_15, HA_C_16), typical of eastern Byzantine production $\left(\mathrm{Al}_{2} \mathrm{O}_{3}\right.$ between $\left.6-7 \%\right)[4,9,64]$. Despite the small number of analysed tesserae, 
different groups can be clearly identified in each of three sites, indicating different supplies: N1 for Milan, N2 for Durrës, and N1 and N3 for Hierapolis.

The glass is a more or less polymerized $\mathrm{SiO}_{4}$ network, each tetrahedron sharing or not its oxygen ion. The $\mathrm{Si}^{4+}$ substitution by $\mathrm{Na}^{+}, \mathrm{K}^{+}, \mathrm{Pb}^{2+}$ and $\mathrm{Ca}^{2+}$ ions lowers the number of strong covalent $\mathrm{Si}-\mathrm{O}$ bonds and hence the melting point. The colouring $3 \mathrm{~d}$ transition ions are hosted in the sites of the $\mathrm{SiO}_{4}$ polymeric network. Non-invasive micro-Raman spectrometry of amorphous silicate phases in glass and enamelled objects has already demonstrated its potential to characterize the glass network $[49,50,55,56,62,65,66]$. The Raman spectrum of an amorphous silicate is composed of two broad bands, the signature of the $\mathrm{SiO}_{4}$ tetrahedra forming the covalent glassy network : the (multicomponent) band centred around $500 \mathrm{~cm}^{-1}$ mainly corresponding to the symmetrical deformation vibrational modes $\left(\delta_{\mathrm{s}} \mathrm{SiO}_{4}\right)$; the second band around 1000 $\mathrm{cm}^{-1}$ corresponds to the symmetric stretching vibrations of the tetrahedron $\left(v_{\mathrm{s}} \mathrm{SiO}_{4}\right)$. Actually, the contribution of asymmetric stretching and bending modes can be neglected $[51,53]$. The number of characteristic components can be reduced to five, each of them corresponds to a different type of $\mathrm{SiO}_{4}$ tetrahedrons forming the silicate polymeric network: isolated tetrahedron or tetrahedral linked by common 1, 2, 3 or 4 oxygen atoms.

According to the above mentioned compositions, the Raman signatures (Fig. 3) can be classified as those typical of soda-lime-silicate glass, corresponding to "Glass family 3" in the Raman signature guide [66]. Only the purple-brown DU_A_6 sample from Durrës shows a slightly different chemical pattern, with better defined $c a .945 \mathrm{~cm}^{-}$ ${ }^{1}$ peak, generally due to higher potassium content (Fig. 4b). According to literature [55, 66], the graphical representation of $v_{\mathrm{S}} \mathrm{SiO}_{4}$ vs. $\delta_{\mathrm{s}} \mathrm{SiO}_{4}$ maximum wavenumber allows to distinguish the types of glass. Fig. $\mathbf{4 b}$ confirms that the tesserae studied in this work are mostly lime-soda glass, only two from Milan are closer to soda glass $[55,66]$. However, their calcium content is lower (Table 1). Two samples (HA_C_15, HA_C_16) from Hierapolis also have low calcium contents, but because of a rather high fluorescence signal covering the Raman's spectra, the Raman signature of the matrix cannot be unambiguously determined .

\subsection{Crystalline dispersed phases}

Apart from the typical spectra of the glass matrix, the most characteristic peaks of various crystalline phases, which serve as pigments and opacifiers, have been detected. The phases identified by Raman are listed in Table 2, and representative spectra are shown in Fig. 5.

The observation under the SEM reveals that some crystals display euhedral shapes that indicate a growth in the molten glassy matrix: According to their sizes they have been classified in two categories:: 1) microcrystals $(>1 \mu \mathrm{m}), 2)$ submicronic crystals (Fig. 2e). The first type is also observed in crystalline aggregates $(20-50 \mu \mathrm{m})$. In many needle-like or geometrically tesserae, the shaped crystals are present in various amounts, particularly in red (Fig. S2b) and yellow pieces. Only sample SA_5_20 (blue glass tesserae) shows dendritic crystals, usually observed as growth in low viscosity liquid phase (Fig. 2f). These crystals are made of calcium and silicium, two of the major glass components. These devitrification crystals, produced when the molten glass is poured into the glass cakes or slabs (at about $\sim 900^{\circ} \mathrm{C}$ ), are not related to colour feature. Wollastonite $\mathrm{CaSiO}_{3}$ Raman fingerprint, with its characteristic stretching peak at 971 $\mathrm{cm}^{-1}$ is identified (Fig. 5d) in the blue tesserae (SA_4_15). 
The opacification of yellow, green, turquoise and blue glass is obtained by the addition of tiny crystallites, dispersed in the glassy matrix identified as follows (Fig. 5 and Table 3).

Calcium antimonate: seven red, blue and grey samples from Milan and Durrës (SA_3_12, SA_3_13, SA_5_20,SA_6_23, HA_C_8, HA_C_11 and HA_C_12; see Fig. 1) show a major peak at $c a .672 \mathrm{~cm}^{-1}$ and less intense ones at $239,324, \overline{3} 4 \overline{0}, 524 \mathrm{~cm}^{-1}$ (Fig. 5c). This series of peaks was recently identified as the Raman signature of calcium antimonate $\left(\mathrm{Ca}_{2} \mathrm{Sb}_{2} \mathrm{O}_{7}\right)$ orthorhombic phase $[3,7,58]$. On the other hand, the Raman signature of one green tessera from Milan (SA_3_10) corresponds to cubic calcium antimonate $\left(\mathrm{CaSb}_{2} \mathrm{O}_{6}\right.$, Fig. 5b) phase with characteristic peaks at $\sim 481$ and $632 \mathrm{~cm}^{-1}$. The spectrum presented in Fig. $\mathbf{5 f}$,characteristic because of the enhanced intensity of $518 \mathrm{~cm}^{-1}$ peak and the presence of $1350-1604 \mathrm{~cm}^{-1}$ carbon doublet, could be explained by a polarisation effect (oriented single crystal spectrum) and/or by the modification of the calcium antimonate signature in relation with some oxygen deficiency. Previous studies on Roman glass $\left(1^{\text {st }}-4^{\text {th }}\right.$ c. $)$ suggested that the presence of calcium antimonate was related to an in situ crystallization [30,67]. It is unknown whether calcium antimonate precursor is added as a natural mineral $\left(\mathrm{Sb}_{2} \mathrm{~S}_{3}\right.$ or pyrochlore) or a previously prepared (synthetic) compound $\left(\mathrm{Sb}_{2} \mathrm{O}_{3}\right)$.

Lead antimonate pyrochlore: eight green, yellow and green-blue tesserae from Hierapolis and Milan (HA_C_1, HA_C_2, HA_C_3, HA_C_4, HA_C_5, HA_C_9, SA_4_17, SA_3_9 and SA_5_20) consistently show three wide peaks at about 335, 452 and $509 \mathrm{~cm}^{-1}$ and a very strong peak at $142 \mathrm{~cm}^{-1}$ (Fig. $5 \mathrm{~g}$ ) associated to bindhemite $\left(\mathrm{PbSb}_{2} \mathrm{O}_{7}\right)$ [3,50,68-70], common in Roman mosaic glass. The submicronic crystals of orthorhombic antimonate and cubic antimonate are often associated to lead antimonate. This phenomenon may be generated by the high temperature $\left(>850^{\circ} \mathrm{C}\right)$, that gives rise to the lead tin yellow [33] decomposition and also produces the devitrification crystal (Fig. 6).

Pyrochlore solid solution (Naples yellow-type pigments): five yellow or yellowgreen tesserae from Durrës (DU_A_1, DU_A_2, DU_A_3, DU_A_4 and DU_A_5) show a strong band at $\sim 130 \mathrm{~cm}^{-1}$ and smalls peak at 320 and $440 \mathrm{~cm}^{-1}$ (Fig. 5h), the Raman signature of pyrochlore bindhemite solid solution $\left(\mathrm{PbSb}_{2-\mathrm{x}-\mathrm{y}} \mathrm{Sn}_{\mathrm{x}} \mathrm{M}_{\mathrm{y}} \mathrm{O}_{7-\delta}\right)$ [71-73].

Cassiterite: four blue and red tesserae from Milan (SA 3 9, SA 3 12,

SA_3_13, SA_4_16) show a major peak at $\sim 635 \mathrm{~cm}^{-1}$ and a smaller peak at $775 \mathrm{~cm}^{-1}$, identified as cassiterite, $\mathrm{SnO}_{2}$ (Fig. 5a, Fig. 2d). Only the second minor band allows clearly distinguishing this compound from orthorhombic calcium antimonate (Fig. $5 \mathbf{b})$ [58].

Quartz: it is added in the glass matrix to obtain a raw opacification in blue and in green tesserae (SA_2_4, SA_3_9, SA_4_15, DU_A_5). The presence of quartz (for example in DU_A_5, Fig. 1c) may enhance the precipitation and the stability of lead antimonates [74]. The stability of the mixture varies according to processing conditions, temperature and time.

Copper-base phases: the Raman spectrum of the orange tessera from Milan (SA 1 1) shows a strong peak at $\sim 220 \mathrm{~cm}^{-1}$ (Fig. 5e) recognized as cuprite $\left(\mathrm{Cu}_{2} \mathrm{O}[73,75]\right)$. Colour and opacity in the red and orange glass (SA_1_1, SA_3_12, HA_C_12) may result from the presence of cuprite crystals and/or metallic copper particles $\left(\mathrm{Cu}^{\circ}\right)$. It is a well-known fact that the control of the copper oxidation state and the production of cuprite crystals require strong technical skills. It is difficult to assess the dominant colouring agent by Raman spectroscopy [23], but copper metal being the most efficient colouring agent and it has furthermore been observed in glass of similar composition and colour [76]. 


\subsection{Technology of opacification}

As referred, three possibilities are available for the opacification process [21, 50, 67, 77]:

1. in situ crystallization during the elaboration process,

2. addition of an opacifier-rich glass called corpo and a yellow pigment called anima to base glass, as reported in ancient recipes [78,79] or

3. addition of previously synthesized opacifying crystals (pigment [7,29]).

The crystalline aggregates of cubic calcium antimonate $\left(\mathrm{CaSb}_{2} \mathrm{O}_{6}\right)$, orthorhombic antimonate $\left(\mathrm{Ca}_{2} \mathrm{Sb}_{2} \mathrm{O}_{7}\right)$ and pyrochlore are probably added to the glass matrix because a zoned phase around the crystal is visible, corresponding to the partial dissolution of crystals in the glass matrix (Fig. 6). However, we remark that in the case of small white crystals $(<1 \mu \mathrm{m})$ the question of technology remains open, because of the dispersion phase absence. Nucleation during complex cooling/heating cycle is likely.

In the tesserae opacified with cassiterite (SA_3_12, SA_4_16, SA_3_13, SA_3_9), larger opacifying crystals $(20-40 \mu \mathrm{m})$ (Fig. $\mathbf{2 d}$ and S2b) are observed, without the dispersion phase. The presence of secondary small micron crystals as shown in Fig. 2d is consistent with the precipitation of the dissolved tin during cooling. Pyrochlore, once mixed/dispersed in a blue matrix, usually is used to produce the shades of yellow and green

For our tesserae the yellow, yellow-green, red and orange colours are obtained by addition of pyrochlore and cuprite or metallic copper, respectively. We have to however denote that in our tesserae the presence of calcium antimonate, cassiterite and quartz is not directly connected to a particular colour (Table 3), as shown in Table 2, but to particular recipes, which can potentially be linked to the specific areas of production (or workshops).

\subsection{Chronology: opacification and mosaic preparation}

The combination Raman and SEM/EDS analyses allow to recognize many types of raw glass and opacification recipes (Table 2).

Calcium antimonates are usually considered as typical Roman opacifying agents. The only known medieval examples of the use of calcium antimonates (excluding reused glass) seem to be the $9^{\text {th }}$-c. enamels (plant-ash sodic glass opacified with calcium carbonate) from St. Ambrose church in Milan [39]. However, in our samples they are also used to produce the mixed glass tesserae (natron/ash, HA_C_10). The coloration and opacification by addition of lead antimonate, allegedly typical of Roman times, is also attested in many Byzantine tesserae, some of them (e.g. those from Durrës, in our case) made with ash plant glass proving a technological continuity at least up to the $8^{\text {th }}$ $9^{\text {th }} \mathrm{c}$. This pigment is also used in Byzantine pottery [80]. We could however demonstrate for some of our tesserae that the opacification technique diverges from Roman technology. The use of cassiterite in the beginning of the $5^{\text {th }} \mathrm{c}$. is proved by the data obtained for the tesserae from St. Aquilino in Milan: these tesserae appear as the most ancient evidence of the use of this mineral, superseding the testimony from the Baptistery of Milan (late $5^{\text {th }}$ c. - beginning of the $6^{\text {th }}$ c.) [6].

Quartz white shades the tesserae. Quartz opacification is used in the Milan and Durrës tesserae, in association with other opacification processes, for example the addition of Naples yellow. Based on the data obtained, the Milan and Durrës tesserae can be considered as the earliest attestation of this technique, previously identified only from the $10^{\text {th }} \mathrm{c}$. onwards $[42,43]$. These new recipes (opacification with cassiterite and quartz), not attested in Roman times, offer an indicator to refine our chronology and to 
identify newly produced tesserae, distinguishing between medieval production and Roman glass recycling.

Our data also allow refining the chronology of the Durrës and Hierapolis mosaics. In Durrës, the use of soda ash glass suggests a post- ${ }^{\text {th }}$ c. chronology; in Hierapolis the use of mixed glass (ash and natron) hints towards a $6^{\text {th }}-7^{\text {th }}$ c. chronology [4].

\section{Conclusion}

The study of the glass ceramic microstructure of coloured/opaque tesserae requires new approaches.

Their very heterogeneous microstructure does prohibits an efficient characterization of the material using LA-ICP methods based on the description of these materials as "homogeneous" glass, as proposed by some authors. Non-destructive Raman microspectroscopy appears as a very efficient technique to compare and classify glass ceramic tesserae. Additional SEM/EDS analysis of representative pieces allowed refining the most debated chronology of the Durrës mosaic (post $8^{\text {th }} \mathrm{c}$.) and the opacification recipes' chronology used in the production of tesserae. The chronological and geographical origins of the technological breakthrough could be identified. In fact, the first use of cassiterite and quartz in the beginning of the $5^{\text {th }} \mathrm{c}$. as well as the use of calcium antimonates after Roman times in the tesserae produced ex novo with mixed glasses were demonstrated. A new production of tesserae (alongside re-using) has been highlighted, based on the analytical identification of clearly distinct recipes from those expected for Roman technology. Analytical data revealed the presence of cassiterite and quartz in natron glass, and of yellow pigments and calcium antimonate in both ash glass (after $8^{\text {th }}$ c.) and mixed glass matrix (after $6^{\text {th }}$ c.). These technological innovations went alongside the continual use of time-honoured Roman recipes (calcium antimonate and yellow pigments).

The above mentioned diverging technological paths, if attested in different regions, could be used as criteria to differentiate supply routes or workshops. For instance, the use of cassiterite recipes in Milan not only diverges from Roman technology, but also from recipes employing in other sites in Italy. In fact, tesserae from churches in Rome (from the $4^{\text {th }}$ to the $12^{\text {th }}$ c. $[26,81-84]$ ) and from Southern Italy (Piazza Armerina, $4^{\text {th }}$ c. [84]; Foggia and Faragola, $6{ }^{\text {th }}$ c. $[86,87]$ show the persistence of a Roman technology (natron base glass with calcium antimonate as opacifier). Tesserae from Ravenna [38,61,88], Vicenza and Padova [40] reveal two different supplies during the $5^{\text {th }}$ century that could be linked to two workshops. The first one produced tesserae with one technique attested in Rome and in southern Italy (natron glass with calcium antimonate); the second producing tesserae with another technique (natron glass with calcium phosphate), as documented in Eastern Mediterranean workshops [15,34-37].

The recipe based on the addition of cassiterite has been recognized in mosaics from Rome only from the $13^{\text {th }} \mathrm{c}$. onwards as well as in some objects manufactured, it was also attested in objects manufactured in the Germanic Kingdom between the $5^{\text {th }}$ and the $7^{\text {th }} \mathrm{c}$. and above all in Celtic enamels [32]. The opacification recipes with cassiterite prove that another route of supply, diverging from those supplying Rome and Ravenna, existed. The previous studies have demonstrated the use of cassiterite for enamel and beads production in India and in Northern Europe [32,89]: the recipe could originate from both areas. Then it must not be excluded that the presence of cassiterite is a marker of a local production in Milan, because it could be identified in $6^{\text {th }}$ c. mosaics of St. John's Baptistery $[6,20]$ and in the later mosaics of St. Ambrose [90].

No reasonable explanation is yet available for the use in the same mosaic of tesserae similar in aspect, but opacified by using different recipes (Table 3). Several 
hypotheses can be proposed. The cakes brought by the mosaicists from another centre have been insufficient to complete the decoration, requiring the use of Italian supply sources (dismantling or new production?). It is also possible to imagine that the tesserae available in Italy were insufficient, requiring the import of glass cakes from another workshops. When in the same site tesserae produced by different techniques are observed, this may suggest a non-local production: if a workshop was in activity close to the site, only one technique should be detected.

By improving the analytical data available for the opacification's recipes used in the production of glass in the Mediterranean area, specific opacification recipes could be geolocalized and the supply routes of mosaicists (from secondary workshops to buildings) could be traced.

\section{Acknowledgments}

The work was partly supported by ORLUCE Convergence Project (SorbonneUniversités, Paris 4 and Paris 6) dedicated to the analysis of glass and gold tesserae from the Western and Eastern areas of the Mediterranean, dated between the 4th and the 9th c.

The authors gratefully acknowledge Francesco d'Andria (University of Salento, Lecce and Maier-Italian archaeological Mission of Hierapolis, Turkey); Marie-Patricia Raynaud (UMR 8167, Orient \& Méditerranée, Monde byzantin, project manager of « Corpus des mosaïques d'Albanie »); Anna Ceresa Mori and Anna Maria Fedeli (Soprintendenza per i beni archeologici della Lombardia), for the kind collaboration and for giving access to the the samples. Dr Anh-Tu Ngo (MONARIS) is kindly acknowledged for his help to use EDX and Dr Thomas Calligaro (C2RMF, Louvre Museum) for the providing Brill and NBS certified glass samples.

\section{References}

[1] L. James, Byzantine glass mosaic tesserae: some material considerations, Byzantine and Modern Greek studies 30 (2006) 29-47.

[2] Ph. Colomban, G. March, L. Mazerolles, T. Karmous, N. Ayed, A. Ennabli, H. Slim, Raman Identification of Materials used for Jewelry and Mosaic in Ifriqiya, J. Raman Spectrosc. 34 (2003) 205-215.

[3] P. Ricciardi, Ph. Colomban, A. Tournié, M. Macchiarola, N. Ayed, A noninvasive study of Roman Age mosaic glass tesserae by means of Raman spectroscopy, J. Archaeol. Sci. 36 (2009) 2551-2559.

[4] N. Schibille, P. Degryse, M. Corremans, Ch. Specht, Chemical characterisation of glass mosaic tesserae from sixth-century Sagalassos (south-west Turkey): chronology and production techniques, J. Archaeol. Sci. 39 (2012) 1480-1492.

[5] L. James, C. Entwistle (Eds.), 2013. New Light on Old Glass: Byzantine Glass and Mosaics, Proceedings of the Conference (London, 27-29 May 2010), British Museum, London.

[6] E. Neri, M. Verità, Glass and metal analyses of gold leaf tesserae from 1st to 9th century mosaics. A contribution to technological and chronological knowledge, J. Archaeol. Sci. 40 (2013) 4596-4606.

[7] E. Basso, C. Invernizzi, M. Malagodi, M.F. La Russa, D. Bersani, P.P. Lottici, Characterization of colorants and opacifiers in Roman glass mosaic tesserae through spectroscopic and spectrometric techniques, J. Raman Spectrosc. 45 (2014) 238-245.

[8] M.D. Nenna, Production et commerce du verre à l'époque impériale: nouvelles découvertes et problématiques, Facta 1 (2007) 125-147. 
[9] I.C. Freestone, The provenance of ancient glass through compositional analysis, Mater. Res. Soc. Symp. Proc. 852 (2005) 1-14.

[10] J. Henderson, Ancient Glass. An interdisciplinary exploration, Cambridge University Press, Cambridge, 2013.

[11] P. Degryse, Glass making in the Graeco-Roman world, Leuven University Press, Leuven, 2014.

[12] A. Silvestri, S. Tonietto, G. Molin, The palaeo-Christian glass mosaic of St. Prosdocimus (Padova, Italy): archaeometric characterisation of 'gold' tesserae, J. Archaeol. Sci. 38 (2011) 3402-3414.

[13] I.C., Freestone, Chemical analysis of raw glass fragments, in: H.R. Hurst (Ed.), Excavation at Carthage, vol. 2, Oxford University Press, Oxford, 1993, p. 290.

[14] J. DeLaine, The Baths of Caracalla, Journal of Roman Archaeology Supplementary Series 25, Portsmouth, 1997.

[15] M.T. Wypyski, Technical Analysis of Glass Mosaic Tesserae from Amorium, DOP 59 (2005) 183-192.

[16] M. Greenhalgh, The survival of Roman antiquities in the Middle Ages, Duckworth, London, 1989.

[17] A. Cutler, The industries of art, in: A.E. Laiou (Ed.), The economic history of Byzantium from the Seventh through the Fifteenth Century, vol. 2, Dumbarton Oaks, Washington, 2002, pp. 555-587.

[18] V. Francois, J.M. Spieser, Pottery and glass in Byzantium, in: A.E. Laiou (Ed.), The economic history of Byzantium from the Seventh through the Fifteenth Century, vol. 2, Dumbarton Oaks, Washington, 2002, 593-610.

[19] N. Schibille, I.C. Freestone, Composition, Production and Procurement of Glass at San Vincenzo al Volturno: An Early Medieval Monastic Complex in Southern Italy, PLOS ONE 8 (10) (2013) e 76479.

[20] E. Neri, Utilisation et production de tesselles de mosaïque à l'époque romane d'après Théophile, in Gestes et techniques de l'artiste à l'époque romane, Cahiers de Cuxà 43 (2012) 31-42.

[21] I. Biron, M.H. Chopinet, Colouring, decolouring and opacifying of glass, in: K. Janssens (Ed.), Modern Methods for Analysing Archeological and Historical Glass, Wiley, New York, 2013, pp. 49-65.

[22] Ph. Colomban, The Use of Metal Nanoparticles to Produce Yellow, Red and Iridescent Colour, from Bronze Age to Present Times in Lustre Pottery and Glass: Solid State Chemistry, Spectroscopy and Nanostructure, J. Nano Res. 8 (2009) 109-132.

[23] Ph. Colomban, H.D. Schreiber, Raman signature modification induced by copper nanoparticles in silicate glass, J. Raman Spectrosc. 36 (2005) 884-890.

[24] Ph. Colomban, A. Tournié, P. Ricciardi, Raman spectroscopy of copper nanoparticle-containing glass matrices: ancient red stained-glass windows, J. Raman Spectrosc. 40 (2009) 1949-1955.

[25] F. Rubio, S. Perez-Villar, M.A. Garrido, J. Rubio, J.L. Oteo, Application of Gradient and Confocal Raman Spectroscopy to Analyze Silver Nanoparticle Diffusion in Medieval Glasses, J. Nano Res. 8 (2009) 89-97.

[26] M. Verità, P. Santopadre, Analysis of gold-colored ruby glass tesserae in Roman church mosaics of the fourth to 12th centuries, J. Glass Stud. 52 (2010) 11-24.

[27] Ph. Colomban, V. Milande, On Site Analysis of the earliest known Meissen Porcelain and Stoneware, J. Raman Spectrosc. 37 (2006) 606-613.

[28] W.E.S. Turner, H.P. Rooksby, A study of opalising agents in ancient opal glasses throughout three thousand four hundred years, Glastechnische Berichte 32K (VII) (1959) 17-28. 
[29] S. Lahlil, I. Biron, L. Galoisy, G. Morin, Rediscovering ancient glass technologies through the examination of opacifier crystals, Appl. Phys. A 92 (2008) 109-116.

[30] S. Lahlil, I. Biron, M. Cotte, J. Susini, New insight on the in situ crystallization of calcium antimonate opacified glass during the Roman period, Appl. Phys. A 100 (2010) 683-692.

[31] M. Uboldi, M. Verità, Scientific analyses of glasses from late Antique to early medieval archaeological sites in northern Italy, J. Glass Stud. 45 (2003) 115-37.

[32] M. Tite, T. Pradell, A. Shortland, Discovery, production an use of tin-based opacifiers in glasses, enamels and glazes from the late iron age onwards: a reassessment, Archaeometry 50 (2008) 67-84.

[33] B. Gratuze, Les verres mosaïqués du secteur de la maison de la Rotonde. Composition chimique et chrono-typologie, in: Ch. Balmelle, A. Bourgeois, H. Broise, J.P. Darmon, M. Ennaifer (Eds.), Carthage, colline de l'Odéon, maison de la Rotonde et Cryptoportique, Ecole Française de Rome, Rome, 2012, pp. 797-801.

[34] A.E. Werner, M. Bismon, Technical report on the glass gaming-pieces, in: I.M. Stead, A La Tène III burial at Welwyn Garden City, Archaeologia 101 (1967) 16-17.

[35] C. Lahanier, Etudes des tesselles de mosaïques et de verre à vitre syriens, in: M.T. Canivet, P. Canivet (Eds.), Huarte, sanctuaire chrétien d'Apamène (IVeVIe s.), Bibliothèque archéologique et historique 122 (1987) 331-346.

[36] R. Newton, D. Davison, Conservation of glass, Routledge, Oxford, 1999.

[37] F. Marii, T. Rehren, Archaeological Coloured Glass Cakes and Tesserae from the Petra Church, in: Annales du 17e congrès de l'Association Internationale pour l'Histoire du Verre (Anvers, septembre 2006), Bruxelles, 2009, pp. 295 300.

[38] M. Verità, Glass mosaic tesserae of the Neonian Baptistry in Ravenna: nature, origin, weathering causes and processes, in: C. Fiori, M. Vandini (Eds.), Ravenna Musiva, Ante Quem, Ravenna, 2010, pp. 89-103.

[39] M. Verità, Indagini analitiche degli smalti dell'altare di Sant'Ambrogio a Milano: transizione verso una nuova tecnologia vetraria nel IX secolo, in M. Vandini (Ed.), Riflessioni e trasparenze: diagnosi e conservazione di opere e manufatti vetrosi, Patron, Bologna, 2010, pp. 11-24.

[40] A. Silvestri, S. Tonietto, G.M. Molin, P. Guerriero, The palaeo-Christian glass mosaic of St. Prosdocimus (Padova, Italy): archaeometric characterisation of tesserae with antimony- or phosphorus-based opacifiers, J. Archaeol. Sci. 39 (2012) 2177-2190.

[41] M. Verità, S. Rapisarda,. Studio analitico di materiali musivi vitrei del XII-XIII secolo dalla Basilica di Monreale a Palermo, Rivista della stazione sperimentale del vetro 2 (2008), 15-29.

[42] R. Arletti, C. Fiori, M. Vandini, A study of glass tesserae from mosaics in the monasteries of Daphni and Hosios Loukas (Greece), Archaeometry 52 (2010) 796-815.

[43] M. Verità, S. Zecchin, Scientific investigations of byzantine glass tesserae from the mosaics on the south chapel of Torcello's Basilica, Venice, in: Annales du 18 e Congrès de l'Association Internationale pour l'Histoire du Verre (Thessaloniki, 20-25 septembre 2009), Thessaloniki, 2012, pp. 315-320.

[44] E. Neri, S. Lusuardi Siena, P. Greppi, Il problema della cronologia del cantiere di S. Lorenzo a Milano. Vecchi e nuovi dati a confronto, Studia ambrosiana 8 (2015) 115-164. 
[45] C. Boschetti, Alcune osservazioni sui mosaici e sulle pitture dell'anfiteatro di Durazzo, in: S. Santoro, A. Hoti, B. Sassi (Eds.), L'anfiteatro di Durazzo. Studi e Scavi 2004-2005, Annuario della Scuola Archeologica Italiana di Atene 83 (III, 5), SAIA, Athens, pp. 789-806.

[46] V. Pace, Mosaici e pittura in Albania (VI-XIV secolo). Stato degli studi e prospettive di ricerca, Antichità Altoadriatiche 53 (2007) 93-128

[47] F. D'Andria, Il santuario e la tomba dell'apostolo Filippo a Hierapolis di Frigia, Rendiconti della Pontificia Accademia Romana di Archeologia LXXXIV (2013) $1-52$.

[48] Ph. Colomban, The on-site/remote Raman analysis with portable instruments: a review of drawbacks and success in Cultural Heritage studies and other associated fields, J. Raman Spectrosc. 43 (2012) 1529-1535.

[49] Ph. Colomban, The destructive/non-destructive identification of enamels, pottery, glass artifacts and associated pigments - A brief overview, Arts 2 (2013) 77-110.

[50] Ph. Colomban, G. Sagon, X. Faurel, Differentiation of antique ceramics from the Raman spectre of their coloured glazes and paintings, J. Raman Spectrosc. 32 (2001) 351-360.

[51] Ph. Colomban, Polymerisation Degree and Raman Identification of Ancient Glasses used for Jewellery, Ceramics Enamels and Mosaics, J. Non-Crystall. Solids 323 (2003) 180-187.

[52] Ph. Colomban, A. Tournié, On-site Raman Identification and Dating of Ancient/Modern Stained Glasses at the Sainte-Chapelle, Paris, J. Cult. Herit. 8 (2007) 242-256.

[53] Ph. Colomban, L.C. Prinsloo, Optical spectroscopy of silicates and glasses, in: J. Yarwood, R. Douthwaite, S. Duckett (Eds.), Spectroscopic properties of inorganic and organometallic compounds: Techniques, Materials and Applications, Volume 40, RSC Publishing, London, 2009, pp. 128-149.

[54] K. Baert, W. Meulebroeck, H. Wouters' A. Ceglia, K. Nys, H. Thienpont, H. Terryn, Raman spectroscopy as a rapid screening method for ancient plain window glass, J. Raman Spectrosc. 42 (2011) 1055-1061.

[55] M.C. Caggiani, C. Valotteau, Ph. Colomban, Inside the glassmaker technology: search of Raman criteria to discriminate between Emile Gallé and PhilippeJoseph Brocard enamels and pigments signatures, J. Raman Spectrosc. 45 (2014) 456-464.

[56] Ph. Colomban, F. Treppoz, Identification and Differentiation of Ancient and Modern European Porcelains by Raman Macro- and Microspectroscopy, J. Raman Spectrosc. 32 (2001) 93-102.

[57] S. Galli, M. Mastelloni, R. Ponterio, G. Sabatino, M. Triscari, Raman and scanning electron microscopy and energy-dispersive X-ray techniques for the characterization of colouring and opaquening agents in Roman mosaic glass tesserae, J. Raman Spectrosc. 35 (2004) 622-627.

[58] V. Gedzevičiūte, N. Welter, U. Schüssler, C. Weiss, Chemical composition and colouring agents of Roman mosaic and millefiori glass, studied by electron microprobe analysis and Raman microspectroscopy, Archeol. and Anthropol. Sci. 1 (2009) 15-29.

[59] E.P. Vicenzi, S. Eggins, A. Logan, R. Wysoczanski, Microbeam characterization of Corning archaeological references glasses. New additions to the Smithsonian microbeam standard collection, J. Research Nat. Inst. Stand. \& Techn. 107 (2002) 719-727. 
[60] J. Henderson, S. Chenery, J. Kröger, E.W. Faber, Glass provenance along the Silk Road: The use of trace element analysis, in: F. Gan, Q. Li and J. Henderson (Eds.), Recent advances in the scientific research on ancient glass and glaze, Series on Archaeology and History of Science in China, Vol. 2, World Scientific, Singapore, 2016, pp. 17-42.

[61] R.H. Brill, Chemical analyses of early glasses: Volume 1 (tables) and 2 (catalogue), Corning Museum of Glass, Corning, 1999.

[62] Ph. Colomban, On-site identification and dating of ancient glasses: a review of procedures and tools, J. Cult. Herit. 9 (Suppl.) (2008) e55-e60.

[63] I. Andreescu Treadgold, J. Henderson, M. Roe, Glass from the Mosaics of the West Wall of Torcello's Basilica, Arte Medievale 2 (2006) 87-140.

[64] T. Rehren, P. Connolly, N. Schibille, H. Schwarzer, Changes in glass consumption in Pergamon (Turkey) from Hellenistic to Late Byzantine and Islamic times, J. Archaeol. Sci. 55 (2015) 266-279.

[65] P. McMillan, B. Piriou, The structural and vibrational spectra of crystals and glasses in the silica-alumina system, J. Non-Cryst. Solids 53 (1982) 279-298.

[66] Ph. Colomban, L. Bellot-Gurlet, A. Tournié, Raman identification of glassy silicates used in ceramics, glass and jewellery: a tentative differentiation guide, J. Raman Spectrosc. 37 (2006) 841-852.

[67] S. Lahlil, I. Biron, L. Galoisy, G. Morin, Technological processes to produce antimonate opacified glass throughout history, Annales du 17e congrès de l'Association Internationale pour l'Histoire du Verre (Anvers, septembre 2006), Bruxelles, 2009, pp. 571-578.

[68] M. Bouchard, D.C. Smith, Catalogue of 45 reference Raman spectra of minerals concerning research in art history or archaeology, especially on corroded metals and coloured glass, Spectrochim. Acta A 59 (2003) 2247-2266.

[69] M. Pereira, T. de Lacerda-Aroso, M.J.M. Gomes, A. Mata, L. C. Alves, Ph. Colomban, Ancient Portuguese Ceramic Wall Tiles (“Azulejos"):

Characterization of the Glaze and Ceramic Pigments, J. Nano Res. 8 (2009) 7988.

[70] B. Kirmizi, Ph. Colomban, B. Quette, On-site analysis of Chinese Cloisonné enamels from fifteenth to nineteenth centuries, J. Raman Spectrosc. 41 (2010) 780-790.

[71] C. Pelosi, U. Santamaria, G. Agresti, E. Mattei, A. De Santis, Production and characterization of lead, tin and antimony based yellow pigments, in: J.H. Townsend, L. Toniolo, F. Cappitelli (Eds.), Proceedings of the International Conference Conservation Science 2007 (Milan 10-11 May, 2007), Archetype Publication, London, 2008, pp. 187-188.

[72] C. Pelosi, G. Agresti, U. Santamaria, E. Mattei, Artificial yellow pigments: production and characterization through spectroscopic methods of analysis, ePreservation Science 7 (2010) 108-115.

[73] Ph. Colomban, A. Tournié, Ph. Meynard, M. Maucuer, On-site Raman and XRF analysis of Japanese/Chinese Bronze/Brass Patina - The search of specific Raman signatures, J. Raman Spectrosc. 43 (6) (2012) 799-808.

[74] S. Paynter, T. Kearns, West Clacton Reservoir, Great Bentley, Essex. Analysis of glass tesserae. Research Department, Report Series, Portsmouth, 2011.

[75] N. Welter, U. Schüssler, W. Kiefer, Characterization of inorganic pigments in ancient glass beads by merans of Raman microspectroscopy, microprobe analysis and X-ray diffractometry, J. Raman Spectrosc. 38 (2007) 113-121.

[76] Ph. Sciau, Ph. Colomban, L. Noé, E. Haudum, Metal nanoparticles in contemporary potters' master pieces: Lustre and red "pigeon blood" pottery: 
Models to understand the ancient technology, Ceram. Int., 42 (2016) 1534915357.

[77] G. Molina, G.P. Odin, T. Pradell, M. Tite, Production technology and replication of lead antimonate yellow glass from New Kingdom Egypt and the Roman Empire, J. Archaeol. Sci. 41 (2014) 171-184.

[78] C. Moretti, S. Hreglich, Opacification and Colouring of Glass by the Use of the "Anime", Glass Technol. 25 (6) (1984) 277-282

[79] L. Zecchin, Il ricettario Darduin: Un codice vetrario del Seicento trascritto e commentato, Arsenale, Venice, 1986.

[80] B. Kirmizi, E.H. Göktürk, Ph. Colomban, Colouring agents in the pottery glazes of Western Anatolia: New evidence for the use of Naples Yellow pigment variations during the late Byzantine period, Archaeometry 57 (2015) 476-496.

[81] M. Verità, Analisi delle tessere musive, in: V. Tiberia (Ed.), I mosaici del XII secolo e di Pietro Cavallini in Santa Maria in Trastevere, Ediart, Todi, 1996, pp. 209-212.

[82] M. Verità, M. Vallotto, Analisi delle tessere musive, in: V. Tiberia (Ed.), Il mosaico di Santa Pudenziana a Roma. Il restauro, Ediart, Todi, 2003, pp. 178199.

[83] M. Verità, P. Santopadre, Le analisi delle tessere musive vitree: esempi d'applicazione nelle indagini preliminari al restauro del mosaico absidale della Cappella dei Santi Primo e Feliciano, in: G. Basile, A. Pandolfi, B. Mazzone, C. Prosperi Porta, M.S. D’Urbano, P. Bianchetti, B. Profilo, P. Santopadre, M. Verità, E. Anselmi, C. D’Angelo, C. Mora, Il restauro del mosaico di S. Stefano Rotondo a Roma, Arte Medievale" 1 (1993) 197-228.

[84] M. Verità, P. Santopadre, Mosaico absidale della basilica di Santa Cecilia a Roma. Studio delle tessere vitree, in: D. Radeglia (Ed.), Restauri a Santa Cecilia. 25 anni di interventi dell'Istituto Superiore per la Conservazione ed il Restauro, Edifir, Florence, 2009, pp. 263-272.

[85] P. Croveri, I. Fragalà, E. Ciliberto, Analysis of glass tesserae from the mosaics of Villa del Casale, near Piazza Armerina: Chemical composition, state of preservation and production technology, Appl. Phys. A 100 (3) (2010) 927-935.

[86] C. Fiori, M. Vandini, M. Macchiarola, G. Ercolani, Studio di vetri musivi di epoca bizantina (V-VI sec.) provenienti da scavi della Capitanata (Foggia), in: C. Piccioli, F. Sogliani (Eds.), Il vetro in Italia meridionale e insulare. Atti del I convegno multidisciplinare (Napoli 5-7 marzo 1998), De Frede, Napoli, 1999, pp. 431-440.

[87] E. Gliozzo, A. Santagostino Barbone, F. D'Acapito, M. Turchiano, I. Memmi Turbanti, G. Volpe, The sectilia panels of Faragola (Ascoli Satriano, Southern Italy): a multi-analytical study of the green, marbled, blue and blackish glass slabs, Archaeometry 50 (3) (2009) 389-415

[88] C. Fiori, M. Vandini, V. Mazzotti, I colori del vetro antico. Il vetro musivo bizantino, Il Prato, Vicenza, 2009.

[89] C. Pion, B. Gratuze, A. De Poorter, Made in India : des perles en verre provenant d'Asie du Sud en Gaule mérovingienne, Bulletin de liaison de l'Association française d'archéologie mérovingienne 37 (2013) 69-71.

[90] C. Fiori, M. Vandini, G. Ercolani, C. Mingazzini, I vetri del mosaico absidale di S. Ambrogio a Milano, Rivista della Stazione Sperimentale del Vetro 29 (1999) 21-29. 
Table 1: Chemical composition of the tesserae glass (expressed in $\mathrm{wt} \%$ of the oxides) and type of glass $(\mathrm{C}$ : sodic plant ash; $\mathrm{N}$ : natron type, $\mathrm{NC}$ : mixed natron-sodic plant ash type; $\mathrm{N} 1$ : $\mathrm{CaO}$ between 4 and 7\%, N2: $\mathrm{CaO}$ between 9 and $11 \%, \mathrm{~N} 3: \mathrm{Al}_{2} \mathrm{O}_{3}$ between 6 and $7 \%$ ). *Only the glass matrix is analyzed.

\begin{tabular}{|l|l|l|l|l|l|l|l|l|l|l|l|l|l|l|l|l|l|l|l|}
\hline Sample & $\mathbf{G l a s s}$ & $\mathbf{N a}_{2} \mathbf{O}$ & $\mathbf{M g O}$ & $\mathbf{A l}_{2} \mathbf{O}_{3}$ & $\mathbf{S i O}_{2}$ & $\mathbf{P}_{2} \mathbf{O}_{5}$ & $\mathbf{S O}_{3}$ & $\mathbf{C l}_{2} \mathbf{O}$ & $\mathbf{K}_{2} \mathbf{O}$ & $\mathbf{C a O}$ & $\mathbf{T i O}_{2}$ & $\mathbf{M n O}_{2}$ & $\mathbf{F e}_{2} \mathbf{O}_{3}$ & $\mathbf{C o}_{3} \mathbf{O}_{4}$ & $\mathbf{C u}_{2} \mathbf{O}$ & $\mathbf{Z n O}$ & $\mathbf{S n O}_{2}$ & $\mathbf{S b}_{2} \mathbf{O}_{5}$ & $\mathbf{P b O}_{2}$ \\
\hline DU_A1* & $\mathrm{C}$ & 12.26 & 2.91 & 1.55 & 69.32 & 0.23 & 0.25 & 0.84 & 2.37 & 9.28 & 0.10 & 0.34 & 0.40 & n.i & 0.09 & n.i. & n.i. & n.i. & n.i. \\
\hline DU_A2 & $\mathrm{N} 2$ & 15.25 & 0.80 & 2.79 & 66.58 & 0.23 & 0.20 & 0.70 & 1.10 & 9.37 & 0.30 & 0.80 & 1.79 & n.i. & 0.10 & n.i. & n.i. & n.i. & n.i. \\
\hline DU_A3* & $\mathrm{C}$ & 12.85 & 2.99 & 1.69 & 65.36 & 0.23 & 0.20 & 0.60 & 2.79 & 10.96 & 0.10 & 1.69 & 0.40 & n.i. & n.i. & 0.13 & n.i. & n.i. & n.i. \\
\hline HA_C_10 & $\mathrm{NC}$ & 18.12 & 0.97 & 2.61 & 62.84 & 0.09 & 0.55 & 1.55 & 1.95 & 5.59 & 0.12 & 0.09 & 0.47 & 0.06 & 0.77 & 0.21 & 0.63 & 1.90 & 1.48 \\
\hline HA_C_12 & $\mathrm{N} 1$ & 14.10 & 0.57 & 2.96 & 66.41 & 0.26 & 0.18 & 1.56 & 0.75 & 7.37 & 0.10 & 0.39 & 0.54 & 0.11 & 0.26 & 0.29 & 0.50 & 2.11 & 1.53 \\
\hline HA_C_13 & $\mathrm{N} 1$ & 16.61 & 0.59 & 2.86 & 63.00 & 0.29 & 0.25 & 1.59 & 0.68 & 7.59 & 0.10 & 0.35 & 0.67 & 0.17 & 0.18 & 0.16 & 0.94 & 2.61 & 1.35 \\
\hline HA_C_15 & $\mathrm{N} 3$ & 18.96 & 0.47 & 6.45 & 60.31 & 0.30 & 0.41 & 1.28 & 0.70 & 4.88 & 0.10 & 0.08 & 0.61 & 0.13 & 0.44 & 0.17 & 0.72 & 1.63 & 2.37 \\
\hline HA_C_16 & $\mathrm{N} 3$ & 16.03 & 2.50 & 6.33 & 63.18 & 0.92 & 0.99 & 0.49 & 0.59 & 5.02 & 0.07 & 0.08 & 1.07 & 0.05 & 0.19 & 0.14 & 0.57 & 1.33 & 0.46 \\
\hline SA-5-20 & $\mathrm{N} 1$ & 23.73 & 0.51 & 3.13 & 61.55 & 0.19 & 0.29 & 1.18 & 0.44 & 4.52 & 0.13 & 0.36 & 0.48 & 0.06 & 0.12 & 0.11 & 0.39 & 0.98 & 1.83 \\
\hline SA-6-18 & $\mathrm{N} 1$ & 18.77 & 0.55 & 3.92 & 62.92 & 0.26 & 0.31 & 1.44 & 0.51 & 3.52 & 0.10 & 0.37 & 0.44 & 0.09 & 1.40 & 0.26 & 0.40 & 2.98 & 1.76 \\
\hline
\end{tabular}

Table 2: Results synthesis: the raw glass group (see Table 1 and text) and the opacification recipes presented by site, chronology and color.

\begin{tabular}{|c|c|c|c|c|}
\hline & & Milan, St. Aquilino & Hierapolis & $\begin{array}{l}\text { Durres, } \\
\text { Amphitheatre chapel }\end{array}$ \\
\hline \multicolumn{2}{|l|}{ Date } & $5^{\text {th }} c$. & $6^{\text {th }} c$. & $8^{\text {th }} \mathrm{c}$. \\
\hline \multicolumn{2}{|l|}{ Raw glass group } & Natron1 & $\begin{array}{l}\text { Natron1, Natron3, } \\
\text { Mixed (soda ash and natron) }\end{array}$ & Natron2, Soda Ash \\
\hline \multirow[t]{3}{*}{$\begin{array}{l}\text { Recipes } \\
\text { of opacification }\end{array}$} & blue & $\begin{array}{l}\text { Calcium antimonate } \\
\left(\mathrm{CaSb}_{2} \mathrm{O}_{6}, \mathrm{Ca}_{2} \mathrm{Sb}_{2} \mathrm{O}_{7}\right) \\
\text { Cassiterite }\left(\mathrm{SnO}_{2}\right) \text {, Quartz }\end{array}$ & $\begin{array}{l}\text { Calcium antimonate } \\
\left(\mathrm{CaSb}_{2} \mathrm{O}_{6}, \mathrm{Ca}_{2} \mathrm{Sb}_{2} \mathrm{O}_{7}\right)\end{array}$ & Bubbles \\
\hline & $\begin{array}{l}\text { green and } \\
\text { yellow }\end{array}$ & $\begin{array}{l}\text { Yellow pigments } \\
\left(\mathrm{PbSb}_{2} \mathrm{O}_{7}\right)\end{array}$ & $\begin{array}{l}\text { Yellow pigments } \\
\left(\mathrm{PbSb}_{2} \mathrm{O}_{7}, \mathrm{PbO}-\mathrm{Pb} 3 \mathrm{O} 4-\mathrm{PbO} 2\right)\end{array}$ & $\begin{array}{l}\text { Yellow pigments, Quartz } \\
\left(\mathrm{PbSb}_{2-}\right)\end{array}$ \\
\hline & red & $\begin{array}{l}\text { Cuprite }\left(\mathrm{Cu}_{2} \mathrm{O}\right) / \\
\mathrm{Cu}^{0} \text { nanoparticles }\end{array}$ & $\begin{array}{l}\mathrm{Cuprite}\left(\mathrm{Cu}_{2} \mathrm{O}\right) / \\
\mathrm{Cu}^{0} \text { nanoparticles }\end{array}$ & $\begin{array}{l}\mathrm{Cuprite}\left(\mathrm{Cu}_{2} \mathrm{O}\right) / \\
\mathrm{Cu}^{0} \text { nanoparticles }\end{array}$ \\
\hline
\end{tabular}


Table 3: Color, provenance (SA: Milan, St. Aquilino (beginning $5^{\text {th }}$ c.); DU: Durrës, amphitheatre chapel $\left(6^{\text {th }}\right.$ c. $-9^{\text {th }}$ c. $)$; HA: Hierapolis, fragment from St. Philip $\left(6^{\text {th }}\right.$ c. $-9^{\text {th }}$ c.), main Raman peaks and phase assignment of coloring /opacifying agents identified in the glass mosaic tesserae.

\begin{tabular}{|c|c|c|c|c|}
\hline Color & Hue & sample & position of peaks $\mathrm{cm}^{-1}$ & phase assignment \\
\hline \multirow{15}{*}{ Blue } & \multirow[t]{2}{*}{ dark blue } & HA_C_8 & $237-325-338-522-671$ & $\mathrm{CaSb}_{2} \mathrm{O}_{6}$ \\
\hline & & HA_C_9 & $142-335-514$ & $\mathrm{PbSb}_{2} \mathrm{O}_{7}$ \\
\hline & \multirow[t]{3}{*}{ blue } & \multirow[t]{2}{*}{ SA_4_15 } & $203-265-355-464$ & $\mathrm{SiO}_{2}$ \\
\hline & & & $326-414-639-971-1043$ & $\mathrm{CaSiO}_{3}$ \\
\hline & & SA_2_4 & $203-262-353-463$ & $\mathrm{SiO}_{2}$ \\
\hline & \multirow[t]{8}{*}{ light blue } & \multirow[t]{2}{*}{ SA_4_16 } & $634-777$ & $\mathrm{SnO}_{2}$ \\
\hline & & & $234-324-337-520-669$ & $\mathrm{CaSb}_{2} \mathrm{O}_{6}$ \\
\hline & & SA_5_20 & $140-335-456-507$ & $\mathrm{PbSb}_{2} \mathrm{O}_{7}$ \\
\hline & & SA_6_23 & $234-324-618-669$ & $\mathrm{CaSb}_{2} \mathrm{O}_{6}$ \\
\hline & & \multirow[t]{3}{*}{ SA_3_9 } & $203-265-356-465$ & $\mathrm{SiO}_{2}$ \\
\hline & & & $636-775$ & $\mathrm{SnO}_{2}$ \\
\hline & & & $140-335-456-507$ & $\mathrm{PbSb}_{2} \mathrm{O}_{7}$ \\
\hline & & HA_C_11 & $234-324-618-669$ & $\mathrm{CaSb}_{2} \mathrm{O}_{6}$ \\
\hline & \multirow[t]{2}{*}{ light blue gray } & HA_C_11 & $236-322-337-522-669$ & $\mathrm{CaSb}_{2} \mathrm{O}_{6}$ \\
\hline & & SA_4_18 & $458-615-639-995-1074$ & alkali sulphate \\
\hline \multirow{17}{*}{$\begin{array}{l}\text { Yellow and } \\
\text { green }\end{array}$} & light turquoise & DU-A9 & $139-339-453$ & $\mathrm{PbSb}_{2-\mathrm{x}} \mathrm{Fe}_{\mathrm{z}} \mathrm{Si}_{\mathrm{u}} \mathrm{O}_{7-\delta}$ \\
\hline & \multirow[t]{2}{*}{ turquoise-green } & HA_C_4 & $140-340-454-511$ & $\mathrm{PbSb}_{2} \mathrm{O}_{7}$ \\
\hline & & HA_C_5 & $142-337-511$ & $\mathrm{PbSb}_{2} \mathrm{O}_{7}$ \\
\hline & green-turquoise & DU-A8 & 456-615-636-997-1078 & alkali sulphate \\
\hline & \multirow[t]{5}{*}{ green } & SA_4_17 & $142-335-452-509$ & $\mathrm{PbSb}_{2} \mathrm{O}_{7}$ \\
\hline & & \multirow[t]{2}{*}{ DU-A5 } & 129-316-437 & $\mathrm{PbSb}_{2-\mathrm{x}} \mathrm{Fe}_{\mathrm{z}} \mathrm{Si}_{\mathrm{u}} \mathrm{O}_{7-\delta}$ \\
\hline & & & $203-260-350-465$ & $\mathrm{SiO}_{2}$ \\
\hline & & SA_3_10 & $324-372-481-632-788-828$ & $\mathrm{Ca}_{2} \mathrm{Sb}_{2} \mathrm{O}_{7}$ \\
\hline & & HA_C_13 & $113-274-507-740$ & $\mathrm{PbO}-\mathrm{Pb}_{3} \mathrm{O}_{4}-\mathrm{PbO}_{2}$ \\
\hline & green yellow & HA_C_3 & $140-337-454-511$ & $\mathrm{PbSb}_{2} \mathrm{O}_{7}$ \\
\hline & \begin{tabular}{|l|} 
yellow green \\
\end{tabular} & HA_C_2 & $142-337-456-511$ & $\mathrm{PbSb}_{2} \mathrm{O}_{7}$ \\
\hline & \multirow[t]{2}{*}{ dark yellow } & HA_C_1 & $142-337-454-511$ & $\mathrm{PbSb}_{2} \mathrm{O}_{7}$ \\
\hline & & DU_A1 & $126-318-438$ & $\mathrm{PbSb}_{2-\mathrm{x}} \mathrm{Fe}_{\mathrm{z}} \mathrm{Si}_{\mathrm{u}} \mathrm{O}_{7-\delta}$ \\
\hline & \multirow[t]{4}{*}{ yellow } & \multirow[t]{2}{*}{ DU_A2 } & $129-316-437$ & $\mathrm{PbSb}_{2-\mathrm{x}} \mathrm{Fe}_{\mathrm{z}} \mathrm{Si}_{\mathrm{u}} \mathrm{O}_{7-\delta}$ \\
\hline & & & $135-263-713-1085$ & $\mathrm{CaCO}_{3}$ \\
\hline & & DU_A3 & $129-318-438$ & $\mathrm{PbSb}_{2-\mathrm{x}} \mathrm{Fe}_{\mathrm{z}} \mathrm{Si}_{\mathrm{u}} \mathrm{O}_{7-\delta}$ \\
\hline & & DU-A4 & $133-324-441$ & $\mathrm{PbSb}_{2-\mathrm{x}} \mathrm{Fe}_{\mathrm{z}} \mathrm{Si}_{\mathrm{u}} \mathrm{O}_{7-\delta}$ \\
\hline \multirow{7}{*}{$\begin{array}{l}\text { Orange and } \\
\text { Red }\end{array}$} & \begin{tabular}{|l|} 
orange \\
\end{tabular} & SA_1_1 & $217-410-636$ & $\mathrm{Cu}_{2} \mathrm{O}$ \\
\hline & \multirow[t]{6}{*}{ Red } & \multirow[t]{5}{*}{ SA_3_12 } & $236-324-337-520-669$ & $\mathrm{CaSb}_{2} \mathrm{O}_{6}$ \\
\hline & & & $634-775$ & $\mathrm{SnO}_{2}$ \\
\hline & & & $467-617-639-995-1076$ & alkali sulphate \\
\hline & & & $634-775$ & $\mathrm{SnO}_{2}$ \\
\hline & & & $217-410-636$ & $\mathrm{Cu}_{2} \mathrm{O} / \mathrm{Cu}^{\circ}$ \\
\hline & & HA_C_20 & $217-410-636$ & $\mathrm{Cu}_{2} \mathrm{O} / \mathrm{Cu}^{\circ}$ \\
\hline White & Gray & HA_C_12 & $239-327-337-522-672$ & $\mathrm{CaSb}_{2} \mathrm{O}_{6}$ \\
\hline
\end{tabular}




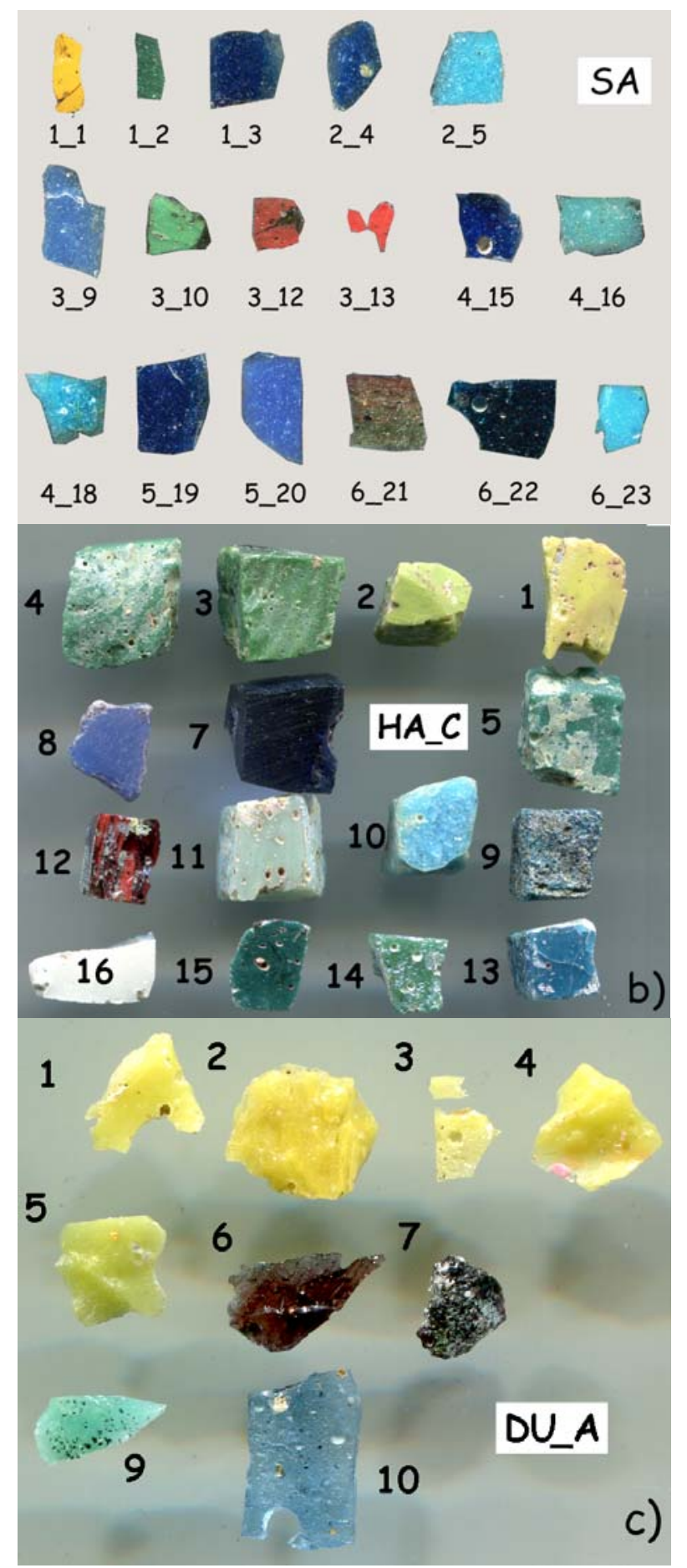

Fig. 1: Tesserae from (a) Milan (SA), (b) Hierapolis (HA_C), (c) Durrës (DU_A); see Supporting information, Table S1 for details. 

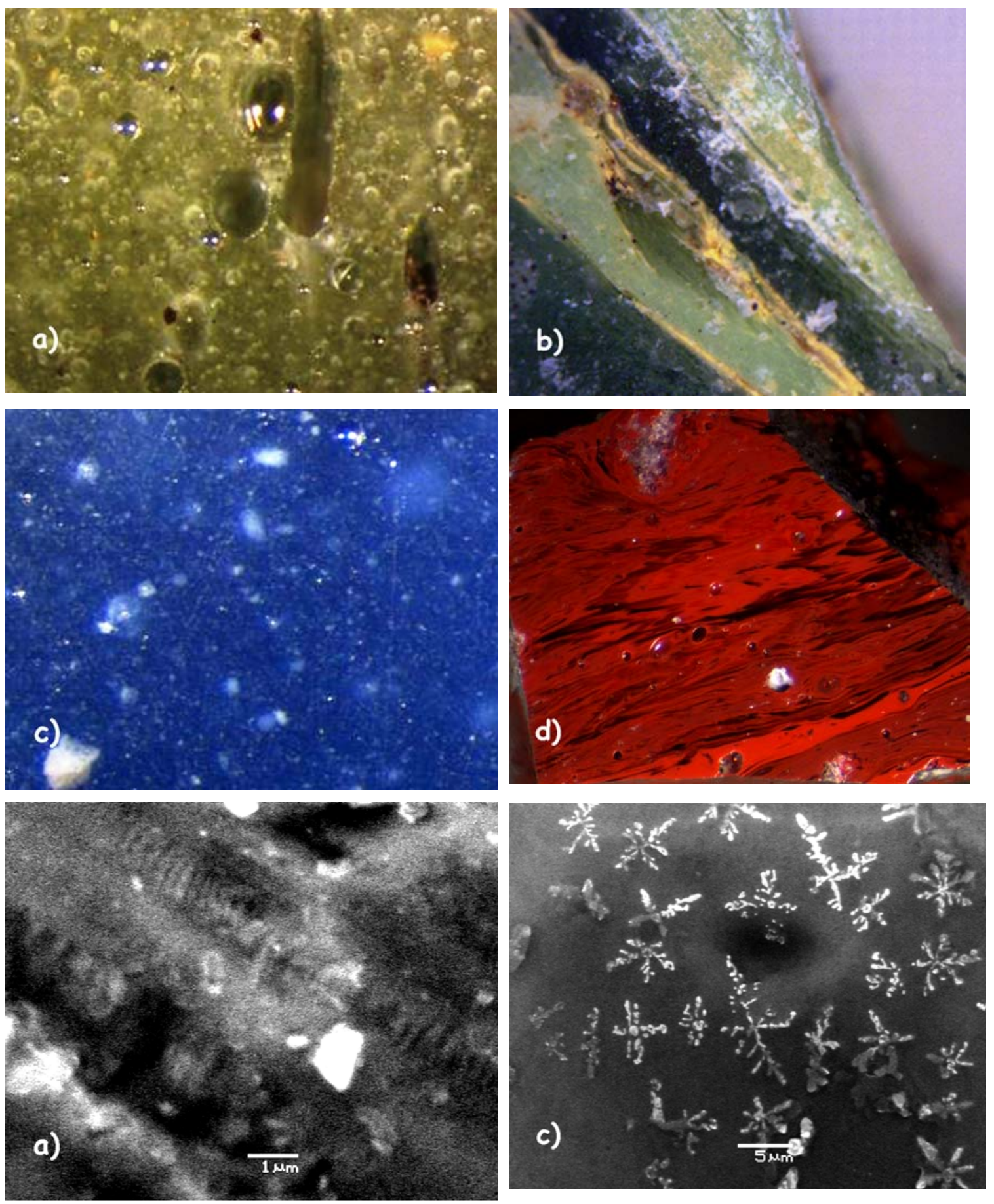

Fig. 2 Typical tesserae microstructures. Optical micrographs: a) green tessera DU_A_5 from Durrës (long side of micrograph $2.4 \mathrm{~mm}$ ), b) green tessera HA_C_2 from Hierapolis (long side of micrograph $3.4 \mathrm{~mm}$ ), c) red tessera HA_C_16 (long side of micrograph $2.3 \mathrm{~mm}$ ), d) blue tessera SA_3_9 from Milan (long side of micrograph $65 \mu \mathrm{m})$. SEM/EDS micrographs: e) faceted crystal and f) dendritic crystals. 


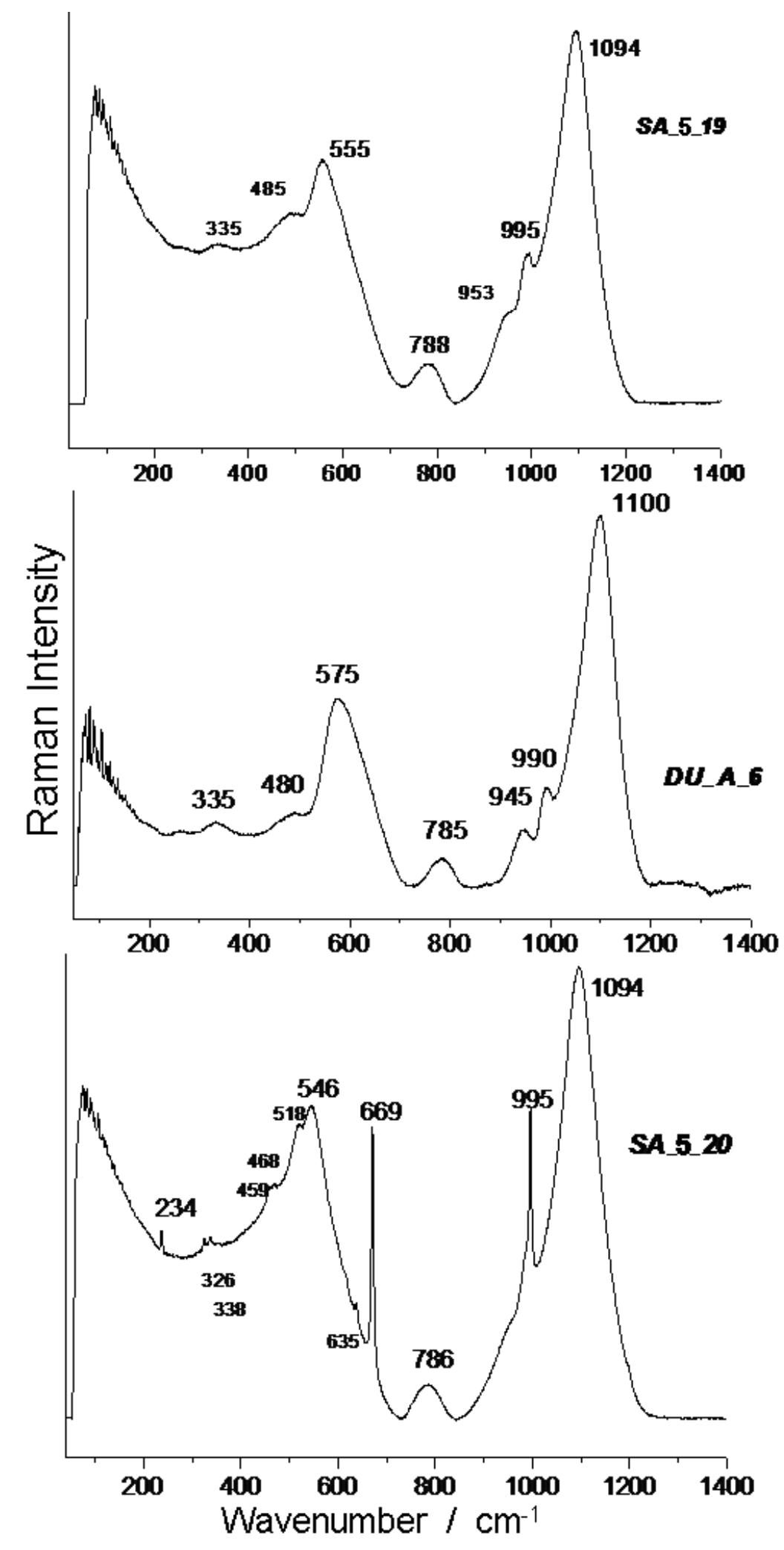

Fig. 3: Typical Raman signature of soda-lime-silica glass matrices (see Fig. 1 and Supporting information, Table S1 for label details). 

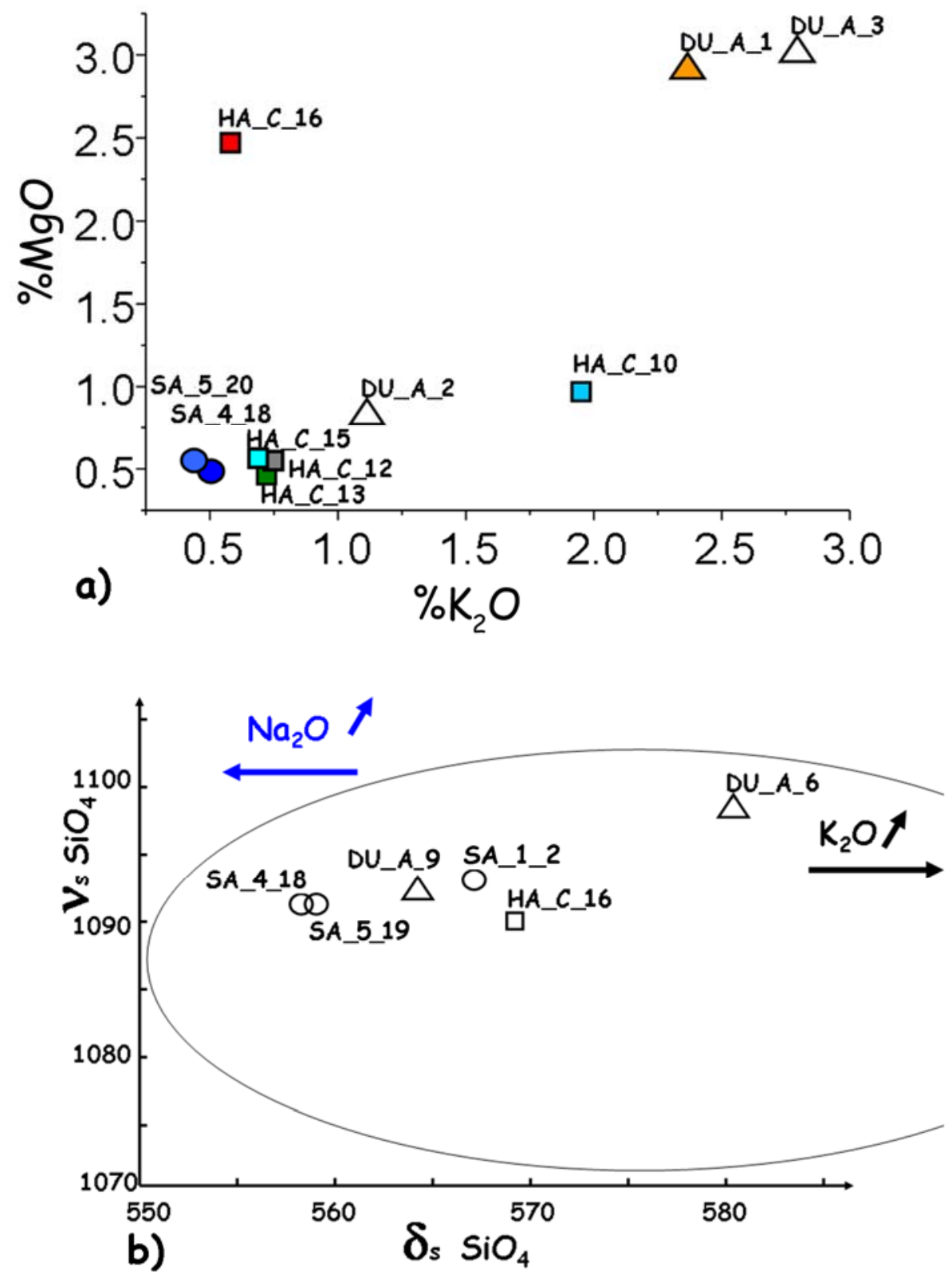

Fig. 4: a) $\mathrm{MgO}$ vs. $\mathrm{K}_{2} \mathrm{O}$ content expressed in $\mathrm{wt} \%$ of oxide of tesserae from Durrës (triangle), Hierapolis (square) and Milan (circle); b) Stretching $\left(v_{\mathrm{s}}\right)$ vs. bending $\left(\delta_{\mathrm{s}}\right)$ band maxima wavenumber of glass matrix for tesserae from Durrës (amphitheatre chapel, triangle), Hierapolis (St Philip, square) and Milan (St Aquilino, circle). The delimited area corresponds to soda-lime glass [55, 66]. Arrows indicate the effect of composition variation $\left(\mathrm{Na}_{2} \mathrm{O}\right.$ and $\mathrm{K}_{2} \mathrm{O}$ increase $)$. 

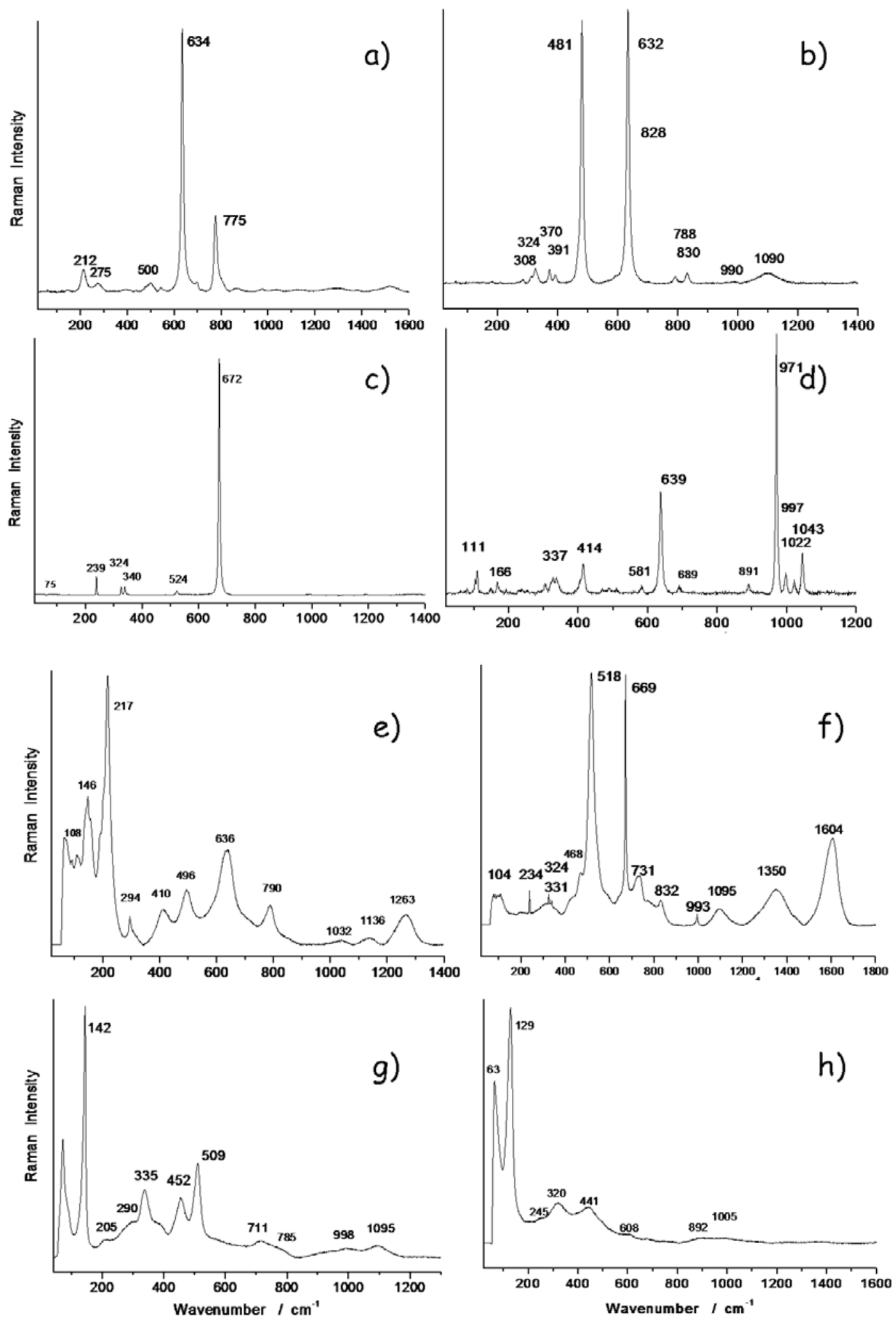

Fig. 5: Representative Raman spectra of the different crystalline phases observed (see text and Table 3 for phase assignments). 


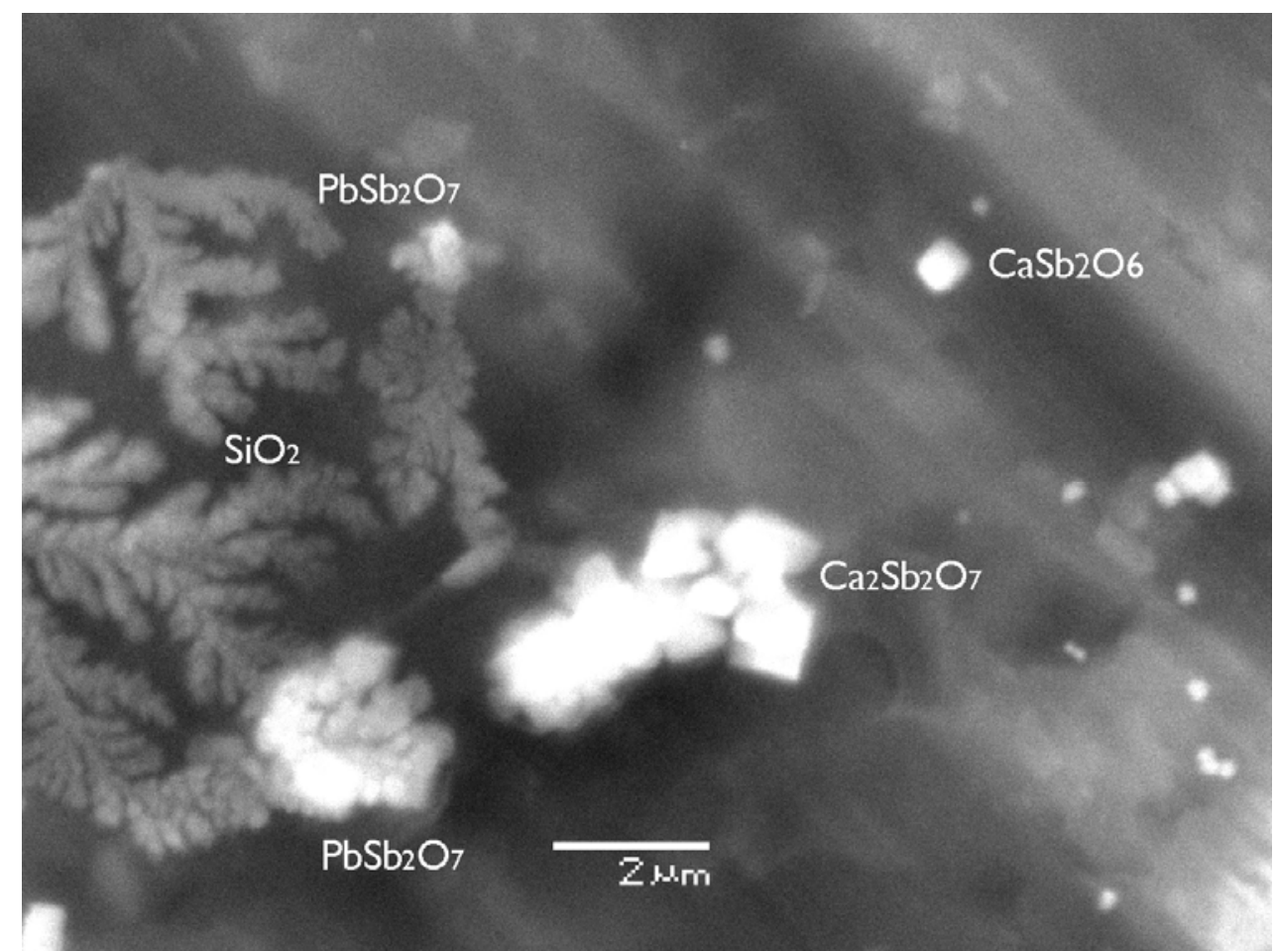

Fig. 6: Crystals observed in sample SA_5_20. 